\title{
Effect of Fungicides, Application Timing, and Canker Removal on Incidence and Severity of Constriction Canker of Peach
}

\author{
Norman Lalancette and Dawn M. Robison, Rutgers University, Agricultural Research and Extension Center, \\ Bridgeton, NJ 08302
}

\begin{abstract}
Lalancette, N., and Robison, D. M. 2002. Effect of fungicides, application timing, and canker removal on incidence and severity of constriction canker of peach. Plant Dis. 86:721-728.

The fungal plant pathogen Phomopsis amygdali, causal agent of constriction canker, initiates infections of peach twigs through petiole scars in fall and bud scale scars and flowers in spring. Fall fungicide treatments, consisting of seven to eight sprays during leaf abscission, reduced canker incidence by 45 to $63 \%$. In contrast, spring applications consisting of four to five sprays from bud-break through bloom, provided only 10 to $28 \%$ control. When applied during both fall and spring, chlorothalonil (46 to $71 \%$ control) and captan (46 to $69 \%$ control) provided the lowest canker incidence and severity, followed by azoxystrobin (41\% control) and myclobutanil ( 28 to $44 \%$ control). Removing cankers by pruning significantly reduced disease incidence by $42 \% 1$ year but had no effect in another year. Possible causes for the inability of any treatment to achieve $>90 \%$ disease control include: (i) none of the fungicides tested were highly effective against the pathogen, (ii) additional infections may have occurred outside the time period during which fungicides were applied, or (iii) use of single-tree plots surrounded by heavily infected nonsprayed trees. Also, the relationship between disease incidence and severity was quantified and observed to be the same for the two cultivars examined. When modeled using the power and quadratic functions, incidence explained $89 \%$ of the variation in severity.
\end{abstract}

Additional keywords: fusicoccum canker, peach canker, phomopsis shoot blight, Prunus persica

Constriction canker of peach is caused by the fungus Phomopsis amygdali (Del.) Tuset \& Portilla (25). During the 1940s and $1950 \mathrm{~s}$ in the Mid-Atlantic Region $(11,13,20,24)$, the pathogen was identified as Fusicoccum amygdali, but recent taxonomic study has indicated that the causal agent belongs to the genus Phomopsis (21). In the southeastern United States, a Phomopsis-induced dieback of peach shoots was observed in Alabama in 1991 (18), and a similar disease caused by a Phomopsis sp. was reported in Georgia in 1997 (23). Subsequently, isolates from Georgia as well as South Carolina were identified as P. amygdali (9). This same pathogen was also recently reported for the first time in California on almond (1).

The pathogen infects peach twigs through fresh leaf scars in the fall and stipules, bud scale scars, blossoms, and fruit scars in the spring $(3,4)$; direct infection through dormant buds has also been recently demonstrated (23). The resulting elongate cankers, centered about twig nodes, are initially reddish brown, but they

Corresponding author: N. Lalancette

E-mail: lalancette@ aesop.rutgers.edu

Current address of D. M. Robison: 617 Marple Ave., Canonsburg, PA 15317.

Accepted for publication 25 February 2002.

Publication no. D-2002-0429-01R

(C) 2002 The American Phytopathological Society become sunken and tan to silver in appearance as they mature. By the summer following infection, the cankers completely girdle and kill the shoots, resulting in the characteristic shoot blight phase of the disease. Because infected shoots are the fruit-bearing shoots for the current growing season, shoot death results in direct fruit loss. Most fruit on infected shoots shrivel and drop off as the shoots desiccate. Shoots having more advanced cankers, usually as a result of fall infection, are often killed before or during bloom and fruit set. A recent quantitative survey in commercial New Jersey orchards in 1997 and 1998 revealed yield losses of 28.5 and $21.0 \%$, which translated into economic losses of $\$ 4,009$ and $\$ 2,803$ per ha, respectively (14).

Given that peak infection occurs in the fall and spring, control measures were initially recommended for these periods $(6,7)$. A review of fungicide efficacy trials conducted from 1940 through 1960 indicated that very effective canker control resulted from the following program: (i) four to eight applications of phenyl mercury at 10 to 20 day intervals during fall leaf drop, (ii) a dormant spray of a Bordeaux mixture plus lead arsenate in the spring, and (iii) delayed dormant and pinkbud sprays of phenyl mercury (5). However, the mercurial and arsenic fungicides were eventually banned from use on crops as foliar sprays. Consequently, subsequent efforts focused on effective substitutes, particularly the dithiocarbamates and ben- zimidazoles, most of which provided levels of control below that obtained with lead arsenate $(5,8)$. Wettable sulfur, a commonly used fungicide in peach, was not toxic to conidial germination and proved ineffective in field trials $(8,10$,$) . Signifi-$ cant canker reductions were reported using fall, dormant, and spring sprays of glyodin plus either thiram, ferbam, or captan (12). This spray program, when supplemented with winter and spring pruning of diseased shoots, allowed rehabilitation of severely disease orchards in 3 years. However, glyodin fungicide, which was considered a critical component for providing lasting protection of buds, is no longer registered for tree fruits.

Growers do not currently incorporate constriction canker control measures into their disease management programs. Few fungicides are registered for use during the critical periods of host susceptibility, particularly the fall, and efficacy of many of the newer active ingredients is unknown. The major objectives of this study designed to investigate management strategies for constriction canker of peach were to: (i) determine relative importance of fall versus spring fungicide application timing, (ii) compare control capabilities of different active ingredients, (iii) examine the ability of sequential years of fungicide usage to rehabilitate infected trees, and (iv) compare canker removal with chemical control measures. In addition, the relationship between disease incidence and severity was explored. Partial results of this study were previously reported (15).

\section{MATERIALS AND METHODS}

Experimental design. Two peach blocks located in a commercial orchard in southern New Jersey were chosen for study which was conducted from fall 1996 through summer 1999. The first block consisted of 10-year-old trees of the cv. Encore, while the second block was comprised of 14-year-old cv. Jerseyglo trees. Both peach blocks were planted at $6 \mathrm{~m} \times 6$ $\mathrm{m}$ tree spacing and had histories of moderate to severe constriction canker. Individual tree canopies in both blocks were approximately 5 to $6 \mathrm{~m}$ in diameter $\times 3.5$ to $4.0 \mathrm{~m}$ high; trees in the Encore block were generally taller than those in the Jerseyglo block. The blocks were located approximately $0.4 \mathrm{~km}$ apart at the orchard and were surrounded by peach blocks of various other cultivars and ages. Air temperature and rainfall data were collected by a 
Solus datalogger (Solus Systems, Inc., Lake Oswego, OR) located approximately $13 \mathrm{~km}$ from the commercial test orchard.

The design employed in each cultivar block was a randomized complete block with five replicates. Treatments were assigned to single-tree plots so that treated trees were surrounded by nontreated buffer trees on all sides. The same treatment-tree assignments were maintained in all 3 years of the study to allow examination of consecutive years of treatment applications on disease control. The Jerseyglo block was removed at the end of the 1998 growing season.

Treatments. Fungicides were applied using a tractor-mounted airblast sprayer (Durand-Wayland AF100-32) traveling at $3.4 \mathrm{~km} / \mathrm{h}$ and calibrated to deliver 935 liter/ha volume at $670-\mathrm{kPa}$ pressure. Fungicides and rates examined in the study were: (i) chlorothalonil (Bravo Weather Stik 6F; Syngenta Crop Protection, Greensboro, NC) at $3.5 \mathrm{~kg}$ a.i./ha, (ii) captan (Captan 50W; Micro Flo Co., Lakeland, FL) at $4.5 \mathrm{~kg}$ a.i./ha, (iii) copper (Tenn-Cop 5E; Griffin Corp., Valdosta, GA) at $360.0 \mathrm{~g}$ a.i./ha, (iv) myclobutanil (Nova 40W; Dow AgroSciences, Indianapolis, IN) at $168.1 \mathrm{~g}$ a.i./ha, (v) azoxystrobin (Abound 2.08F; Syngenta Crop Protection) at $280.2 \mathrm{~g}$ a.i./ha, and (vi) benomyl (Benlate 50W; E. I. DuPont de Nemours and Co., Wilmington, DE) at $1.1 \mathrm{~kg}$ a.i./ha. Control treatment trees received no fungicide sprays during treatment periods. Chlorothalonil, captan, and myclobutanil were examined at both sites for all 3 years of the study. The remaining three fungicides were added to the study in 1998 or 1999 at either or both sites.

To examine the importance of application timing, chlorothalonil was applied under three different timing scenarios: (i) during the fall leaf abscission period, (ii) during the spring bud-break to bloom period, and (iii) during both fall and spring periods. Similarly, two captan treatments at seasonal timings (ii) and (iii) also were examined. All other fungicides were applied during both fall and spring (timing scenario iii) with a spray interval of approximately 10 days (Table 1 ). During the summer, all trees in both blocks received standard cover sprays of captan (Captan 50WP) at $2.25 \mathrm{~kg}$ a.i./ha and preharvest brown rot sprays of propiconazole (Orbit 3.6E; Syngenta Crop Protection) at $126.1 \mathrm{~g}$ a.i./ha; similarly, insecticides and herbicides were applied throughout the study according to standard practices (2).

A cultural control treatment was evaluated in the Encore block during the latter 2 years of the study. Five trees, one per replicate, were randomly selected from extra nonsprayed trees located in the test block. From early to mid-September of 1997 and 1998, prior to leaf abscission, all constriction cankers were removed from each chosen tree by pruning. Culled cankers were not removed from the block and allowed to remain on the orchard floor below the test trees. In 1997, the total number of pruned cankers was recorded for each tree.

Disease assessment. During early to mid-September in 1996, 1997, and 1998, 50 healthy-appearing current-season shoots, uniformly distributed throughout the canopy, were tagged on each tree. In each subsequent summer, from mid-June through the end of July, the number of constriction cankers was counted and the percent infected shoots (disease incidence) and average number of cankers per shoot (disease severity) were calculated. Percent disease control $(d c)$ was calculated using the formula

$$
d c=\left[\left(d i_{n s}-d i_{t r t}\right) / d i_{n s}\right] \times 100
$$

where $d i_{n s}=$ percent disease incidence for the nonsprayed treatment and $d i_{t r t}=$ percent disease incidence for a given treatment. To obtain an overall measure of control level for each treatment, averages of both $d i_{n s}$ and $d i_{t r t}$ were obtained across all years before calculation of $d c$ using the above formula.

Statistical analysis. Analysis of variance (ANOVA) was performed for each cultivar using the general linear models (glm) procedure of the Statistical Analysis System v7.0 (SAS Institute, Inc., Cary, NC). Application timing, year, and replicate effects were examined, as well as planned contrasts comparing fall, spring, and fall + spring timings. In addition, separate ANOVAs were performed for each cultivar-year combination to allow for specific treatment comparisons using the Waller-Duncan $k$-ratio $t$ test. Residual analysis, normal probability plots, and the Shapiro-Wilk test for normality were performed on both dependent variables. The arcsine-square root and square-root transformations were applied to disease incidence and severity data, respectively. Per- cent disease control among treatments was compared graphically by plotting histograms of 2 and 3 year means for the Jerseyglo and Encore orchards, respectively.

Cumulative treatment effects over the 3year period were examined by calculating rates of disease change between consecutive years for each of the treatment replicates. Standard two-sided $t$ tests were performed $\left(\mathrm{H}_{0}:\right.$ rate $=0 ; \mathrm{H}_{\mathrm{a}}$ : rate $\left.\neq 0\right)$ on these rates to determine if disease levels changed over time. Negative and positive slopes indicated decreasing and increasing disease levels, respectively, from one year to the next year.

The treatments in this study produced a wide range of disease levels across the various years and replicates, thereby providing an opportunity to examine the relationship between disease incidence and severity. This relationship was quantified by fitting the exponential, power, and quadratic models to the combined cultivar data sets using nonlinear regression analysis (nlin procedure, SAS Institute, Inc., Cary, NC). The best model was determined graphically by comparing predicted values to observed data points, and by examination of the coefficients of determination. Once the appropriate incidence-severity function was determined, separate models were generated for each cultivar data set. Full and reduced regression models were then compared to determine if significant differences in parameter estimates existed for each cultivar incidence-severity model.

\section{RESULTS}

Environmental conditions were favorable for disease development during the study. Corresponding fall and spring seasons had similar conditions except in fall 1998, when temperatures were warmer and rainfall was reduced relative to 1996 to 1997. During the fall leaf abscission period (01 Sep to $30 \mathrm{Nov}$ ), the average temperature, number of rainfall events $(>0.25 \mathrm{~cm})$, and total rainfall accumulations were: $14.5^{\circ} \mathrm{C}, 16$, and $23.1 \mathrm{~cm}$ in $1996,14.6^{\circ} \mathrm{C}$, 21 , and $22.8 \mathrm{~cm}$ in 1997 , and $16.9^{\circ} \mathrm{C}, 11$, and $12.0 \mathrm{~cm}$ in 1998 . During the spring bud-break through bloom period (15 Mar to 15 May), the average temperature, number of rainfall events $(>0.25 \mathrm{~cm})$, and total rainfall accumulation were: $10.8^{\circ} \mathrm{C}, 18$, and $20.4 \mathrm{~cm}$ in $1997,13.1^{\circ} \mathrm{C}, 13$, and 19.4 $\mathrm{cm}$ in 1998 , and $13.2^{\circ} \mathrm{C}, 11$, and $18.0 \mathrm{~cm}$ in 1999.

Table 1. Fungicide application dates and spray intervals evaluated experimentally for control of constriction canker, caused by Phomopsis amygdali, in cvs. Encore and Jerseyglo peach trees

\begin{tabular}{|c|c|c|c|c|c|c|c|c|c|c|c|}
\hline \multirow[b]{2}{*}{ Year } & \multirow[b]{2}{*}{ Season } & \multicolumn{8}{|c|}{ Application date } & \multicolumn{2}{|c|}{ Interval (days) } \\
\hline & & 1 & 2 & 3 & 4 & 5 & 6 & 7 & 8 & Range & Mean \\
\hline 1996 & Fall & $07 \mathrm{Sep}$ & $17 \mathrm{Sep}$ & $27 \mathrm{Sep}$ & 08 Oct & 18 Oct & 28 Oct & $07 \mathrm{Nov}$ & $20 \mathrm{Nov}$ & $9-13$ & 10.4 \\
\hline \multirow[t]{2}{*}{1997} & Spring & $02 \mathrm{Apr}$ & $10 \mathrm{Apr}$ & $17 \mathrm{Apr}$ & $25 \mathrm{Apr}$ & 08 May & & & $\ldots$ & $7-13$ & 9.0 \\
\hline & Fall & $08 \mathrm{Sep}$ & 18 Sep & $02 \mathrm{Oct}$ & $13 \mathrm{Oct}$ & $23 \mathrm{Oct}$ & $03 \mathrm{Nov}$ & $12 \mathrm{Nov}$ & $\ldots$ & $9-14$ & 10.8 \\
\hline \multirow[t]{2}{*}{1998} & Spring & $01 \mathrm{Apr}$ & $14 \mathrm{Apr}$ & $22 \mathrm{Apr}$ & 07 May & $\ldots$ & $\ldots$ & $\ldots$ & $\ldots$ & $8-15$ & 12.0 \\
\hline & Fall & $03 \mathrm{Sep}$ & 15 Sep & $25 \mathrm{Sep}$ & $10 \mathrm{Oct}$ & $20 \mathrm{Oct}$ & 30 Oct & $09 \mathrm{Nov}$ & $19 \mathrm{Nov}$ & $10-15$ & 11.3 \\
\hline 1999 & Spring & 17 Mar & 29 Mar & $08 \mathrm{Apr}$ & 19 Apr & $29 \mathrm{Apr}$ & $\ldots$ & $\ldots$ & $\ldots$ & $10-12$ & 10.8 \\
\hline
\end{tabular}


Application timing. ANOVA of disease incidence and severity for the fall, spring, and fall + spring Bravo and Captan treatments resulted in highly significant $(P<$ $0.0001)$ application timing effects for Encore (Table 2). In contrast, the Jerseyglo timing effects were much less significant with $P$ values of only 0.07 and 0.08 for the incidence and severity data, respectively. Year had no effect on the Encore results, which were estimated over all 3 years of the study. However, on Jerseyglo, results from the 1997 and 1998 years were somewhat different, particularly for the severity data $(P=0.007)$.

In specific contrasts on both cultivars, the importance of the fall application timing appeared evident (Table 2). On Encore, both fall and fall + spring application timings were significantly different from those treatments receiving only spring sprays. However, only the latter comparison, fall + spring versus spring, was observed significant on Jerseyglo ( $P \leq 0.05$ ). Nevertheless, in both orchards no difference was observed when comparisons were made between treatment types that contained fall applications, namely fall + spring versus fall.

Results from mean comparisons among the five fungicide-timing treatment combinations and nonsprayed control agree with the specific ANOVA contrasts (Table 3). In all 3 years of work in the Encore orchard, application of either chlorothalonil or captan during the fall or fall + spring timing periods provided significantly $(P \leq 0.05)$ lower incidence and severity of constriction canker than observed on trees treated only in spring or on nonsprayed trees. Furthermore, incidence and severity results from the fall + spring chlorothalonil sprays in 1997 and 1998 were not significantly different from those obtained by only spraying in the fall. However, in 1999, the addition of spring chlorothalonil applications to the fall schedule provided significantly better disease control than the fallonly timing. This improved efficacy for the combined treatment schedule in 1999 may have been due to the earlier spring application timing employed in that year (Table 1). The effect of this earlier timing also appears to be evident in the spring-only treatments. In 1999, spring applications of either fungicide resulted in significantly less disease than on nonsprayed trees, while trees receiving the same treatments in 1997 and 1998 had statistically similar or more disease than those not treated.

Results from the Jerseyglo block were less definitive, as previously exemplified by the fewer number of significant contrasts (Table 3). Most corresponding treatment trees had higher disease incidence and severity levels than observed on Encore in the same years. In 1997, fall or fall

Table 2. Analysis of variance and comparison of application timings for peach constriction canker incidence and severity in two cultivars during 1997, 1998, and 1999

\begin{tabular}{|c|c|c|c|c|c|c|c|}
\hline \multirow[b]{2}{*}{ Source } & \multicolumn{4}{|c|}{ Proportion infected shootsw } & \multicolumn{3}{|c|}{ No. cankers per shoot ${ }^{x}$} \\
\hline & df & MS & $F$ value & $P>F$ & MS & $F$ value & $P>\mathbf{F}$ \\
\hline \multicolumn{8}{|l|}{ Encore orchardy } \\
\hline Model $^{\mathrm{z}}$ & 8 & 0.2347 & 14.18 & $<0.0001$ & 0.1376 & 12.92 & $<0.0001$ \\
\hline Replicate & 4 & 0.0189 & 1.14 & 0.3460 & 0.0146 & 1.37 & 0.2523 \\
\hline Year & 2 & 0.0003 & 0.02 & 0.9808 & 0.0015 & 0.14 & 0.8706 \\
\hline Application timing & 2 & 0.9008 & 54.42 & $<0.0001$ & 0.5197 & 48.78 & $<0.0001$ \\
\hline Fall versus spring & 1 & 0.8294 & 50.10 & $<0.0001$ & 0.5079 & 47.67 & $<0.0001$ \\
\hline Fall + spring versus spring & 1 & 1.6177 & 97.73 & $<0.0001$ & 0.9147 & 85.86 & $<0.0001$ \\
\hline Fall + spring versus fall & 1 & 0.0163 & 0.99 & 0.3242 & 0.0047 & 0.44 & 0.5107 \\
\hline Error & 66 & 0.0166 & $\ldots$ & $\ldots$ & 0.0107 & $\ldots$ & $\ldots$ \\
\hline \multicolumn{8}{|l|}{ Jerseyglo orchardc } \\
\hline Model $^{\mathrm{d}}$ & 7 & 0.0312 & 1.43 & 0.2172 & 0.0403 & 2.18 & 0.0555 \\
\hline Replicate & 4 & 0.0019 & 0.09 & 0.9864 & 0.0084 & 0.46 & 0.7666 \\
\hline Year & 1 & 0.0867 & 3.98 & 0.0525 & 0.1508 & 8.17 & 0.0066 \\
\hline Application timing & 2 & 0.0623 & 2.86 & 0.0685 & 0.0486 & 2.63 & 0.0836 \\
\hline Fall versus spring & 1 & 0.0637 & 2.92 & 0.0947 & 0.0246 & 1.33 & 0.2552 \\
\hline Fall + spring versus spring & 1 & 0.1078 & 4.95 & 0.0315 & 0.0962 & 5.21 & 0.0276 \\
\hline Fall + spring versus fall & 1 & 0.0002 & 0.01 & 0.9153 & 0.0093 & 0.50 & 0.4815 \\
\hline Error & 42 & 0.0218 & $\ldots$ & $\ldots$ & 0.0185 & $\ldots$ & $\ldots$ \\
\hline
\end{tabular}

${ }^{\mathrm{w}}$ Analyses performed on transformed disease incidence data: arcsine[square root (proportion)].

${ }^{x}$ Analyses performed on transformed disease severity data: square root (value +0.5 ).

y Encore data encompassed all 3 years of the study, while cv. Jerseyglo data was only from 1997 and 1998.

${ }^{\mathrm{z}}$ Treatments included in model: fall, spring, and fall + spring application timings of Bravo; spring and fall + spring application timings of Captan.

Table 3. Comparison of fungicide timing for management of constriction canker in two commercial peach orchards over a 2-or 3-year period

\begin{tabular}{|c|c|c|c|c|c|c|}
\hline \multicolumn{2}{|c|}{ Treatment } & \multicolumn{3}{|c|}{ Encore orchard ${ }^{y}$} & \multicolumn{2}{|c|}{ Jerseyglo orchard ${ }^{y}$} \\
\hline Fungicide & Timing ${ }^{z}$ & 1997 & 1998 & 1999 & 1997 & 1998 \\
\hline \multicolumn{7}{|c|}{ Disease incidence (\% infected shoots) } \\
\hline Nonsprayed & $\ldots$ & $51.8 \mathrm{a}$ & $39.5 \mathrm{~b}$ & $57.2 \mathrm{a}$ & $54.2 \mathrm{a}$ & $54.6 \mathrm{a}$ \\
\hline \multirow[t]{3}{*}{ Chlorothalonil } & Fall & $18.3 \mathrm{c}$ & $10.8 \mathrm{c}$ & $26.1 \mathrm{c}$ & $34.4 \mathrm{~b}$ & $25.2 \mathrm{bc}$ \\
\hline & Spring & $48.9 \mathrm{a}$ & $47.5 \mathrm{ab}$ & $37.4 \mathrm{~b}$ & $40.8 \mathrm{ab}$ & $37.0 \mathrm{~b}$ \\
\hline & Fall + spring & $16.5 \mathrm{c}$ & $13.9 \mathrm{c}$ & $12.7 \mathrm{~d}$ & $31.9 \mathrm{~b}$ & $27.2 \mathrm{bc}$ \\
\hline \multirow[t]{2}{*}{ Captan } & Spring & $39.3 \mathrm{ab}$ & $52.2 \mathrm{a}$ & $36.5 \mathrm{~b}$ & $41.0 \mathrm{ab}$ & $38.2 \mathrm{~b}$ \\
\hline & Fall + spring & $13.6 \mathrm{c}$ & $12.1 \mathrm{c}$ & $21.0 \mathrm{c}$ & $37.8 \mathrm{ab}$ & $21.4 \mathrm{c}$ \\
\hline \multicolumn{7}{|c|}{ Disease severity (No. cankers per shoot) } \\
\hline Nonsprayed & $\ldots$ & $0.96 \mathrm{a}$ & $0.77 \mathrm{a}$ & $1.15 \mathrm{a}$ & $1.07 \mathrm{a}$ & $1.44 \mathrm{a}$ \\
\hline \multirow[t]{3}{*}{ Chlorothalonil } & Fall & $0.23 \mathrm{c}$ & $0.12 \mathrm{~b}$ & $0.36 \mathrm{c}$ & $0.64 \mathrm{ab}$ & $0.34 \mathrm{~b}$ \\
\hline & Spring & $0.73 \mathrm{ab}$ & $0.81 \mathrm{a}$ & $0.55 \mathrm{~b}$ & $0.68 \mathrm{ab}$ & $0.54 \mathrm{~b}$ \\
\hline & Fall + spring & $0.24 \mathrm{c}$ & $0.20 \mathrm{~b}$ & $0.17 \mathrm{~d}$ & $0.54 \mathrm{~b}$ & $0.34 \mathrm{~b}$ \\
\hline \multirow[t]{2}{*}{ Captan } & Spring & $0.61 \mathrm{~b}$ & $0.86 \mathrm{a}$ & $0.54 \mathrm{~b}$ & $0.73 \mathrm{ab}$ & $0.49 \mathrm{~b}$ \\
\hline & Fall + spring & $0.14 \mathrm{c}$ & $0.14 \mathrm{~b}$ & $0.29 \mathrm{~cd}$ & $0.51 \mathrm{~b}$ & $0.25 \mathrm{~b}$ \\
\hline
\end{tabular}

${ }^{y}$ For each type of disease assessment, means in the same column with the same letters do not differ significantly according to the Waller-Duncan $k$-ratio $t$ test at $P \leq 0.05$ and $k=100$. Each mean was calculated from 5 replicate trees with 50 shoots per tree.

${ }^{\mathrm{z}}$ Timing indicates the season(s) that fungicides were applied; specific application dates for each year and season are given in Table 1. 
+ spring applications of chlorothalonil resulted in significantly less canker incidence than on nonsprayed trees; only the combined fall + spring programs for either fungicide reduced canker numbers. In 1998, all fungicide-treated trees had significantly less disease incidence and severity than the nonsprayed trees, however, little or no statistical differentiation was observed among disease levels for the various timing regimes. Nevertheless, a comparison of treatment mean values in both years showed the same pattern that was observed in Encore, namely that those trees receiving fall or fall + spring applications had the lowest disease levels.

For both cultivars, the best disease suppression over the course of the study was achieved with treatments that incorporated fall applications (Fig. 1). For these treatments, fall or fall + spring percent disease control was higher on Encore than on Jerseyglo. In contrast, the level of disease control on Jerseyglo was greater than on Encore for both captan and chlorothalonil applied only in spring. The overall best disease control occurred with chlorothalonil applied in the fall and spring on Encore ( $71 \%$ disease control) followed closely by captan at the same timing (69\% control).

Fungicides and cultural control. When applied at similar schedules in the fall and spring, most fungicides significantly reduced disease levels relative to the nonsprayed treatment (Table 4). Across all years on Encore, disease incidence and

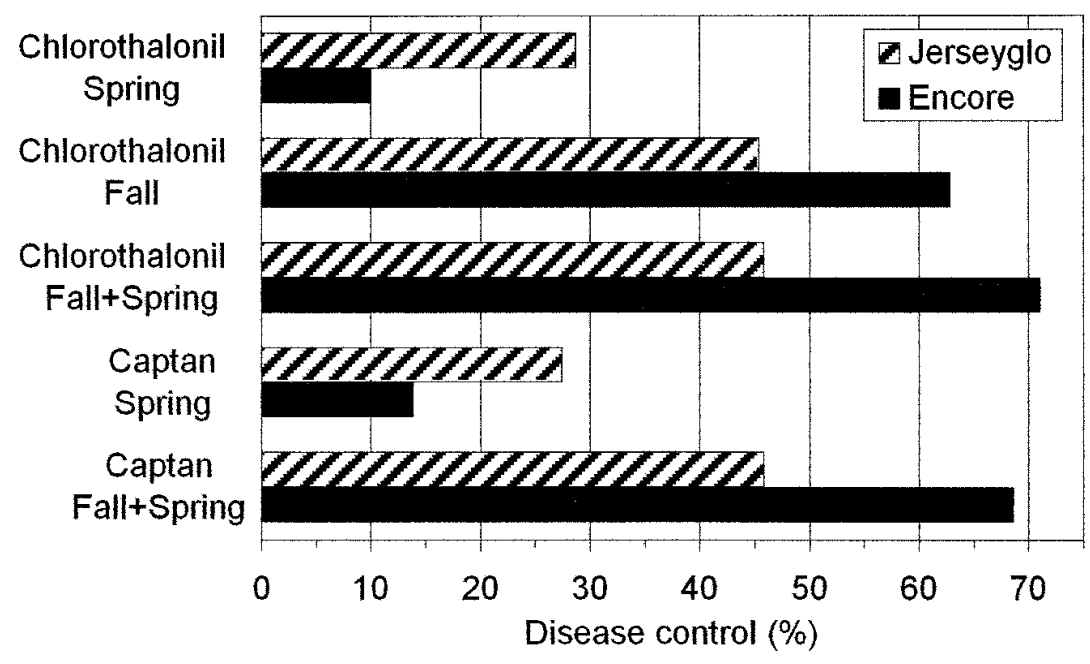

Fig. 1. Effect of fungicide application timing on control of peach constriction canker caused by Phomopsis amygdali. Data are averaged over 3 years for cv. Encore, and 2 years for cv. Jerseyglo. Specific dates of application within each season are given in Table 1. severity was significantly reduced in 79 and $93 \%$ of 14 fungicide treatments evaluated, respectively. Similarly, for the 2 years of study in the Jerseyglo block, $86 \%$ of seven fungicide treatments had significantly less disease incidence and severity than the nonsprayed control.

Good to excellent fungicide treatment mean separation was observed for the Encore block, while no separation occurred for the Jerseyglo block (Table 4). Over all 3 years of the study on Encore, chlorothalonil and captan consistently provided the lowest disease incidence and severity levels. However, in 1997, myclobutanil reduced disease incidence to the same levels as chlorothalonil and captan. Similarly in 1999, canker incidence and severity levels were statistically identical in azoxystrobinand captan-treated trees, but the former still had significantly higher disease levels than obtained with chlorothalonil.

For the cultural control treatment, the five replicate trees pruned in September 1997 averaged 640 cankers per tree on 342 infected shoots per tree. The large number of shoots removed was indicative of the high disease severity of constriction canker in the Encore block. Removal of these cankers from the trees did not result in lower disease incidence or severity in 1998 (Table 4). However, the fall 1998 pruning treatment significantly reduced the number of new cankers in 1999 relative to the increased disease level on the nonsprayed control trees. Nevertheless, in both years, the degree of disease control from canker removal was less than that observed with the best fungicides.

Overall disease control on Encore was best when either chlorothalonil or captan were used, followed by azoxystrobin (Fig.

Table 4. Comparison of fungicides and canker removal by pruning for management of constriction canker in two commercial peach orchards over a 2- or 3-year period

\begin{tabular}{|c|c|c|c|c|c|}
\hline \multirow[b]{2}{*}{ Fungicide $^{\mathrm{y}}$} & \multicolumn{3}{|c|}{ Encore orchard $^{\mathrm{x}}$} & \multicolumn{2}{|c|}{ Jerseyglo orchard $^{\mathrm{x}}$} \\
\hline & 1997 & 1998 & 1999 & 1997 & 1998 \\
\hline \multicolumn{6}{|c|}{ Disease incidence (\% infected shoots) } \\
\hline Nonsprayed & $51.8 \mathrm{a}$ & $39.5 \mathrm{a}$ & $57.2 \mathrm{a}$ & $54.2 \mathrm{a}$ & $54.6 \mathrm{a}$ \\
\hline Chlorothalonil & $16.5 \mathrm{~b}$ & $13.9 \mathrm{~b}$ & $12.7 \mathrm{e}$ & $31.9 \mathrm{~b}$ & $27.2 \mathrm{~b}$ \\
\hline Captan & $13.6 \mathrm{~b}$ & $12.1 \mathrm{~b}$ & $21.0 \mathrm{~d}$ & $37.8 \mathrm{ab}$ & $21.4 \mathrm{~b}$ \\
\hline Myclobutanil & $28.5 \mathrm{~b}$ & $32.7 \mathrm{a}$ & $46.2 \mathrm{~b}$ & $35.6 \mathrm{~b}$ & $25.7 \mathrm{~b}$ \\
\hline Copper & $\ldots$ & $33.6 \mathrm{a}$ & $39.3 \mathrm{bc}$ & $\ldots$ & $30.9 \mathrm{~b}$ \\
\hline Azoxystrobin & $\ldots$ & $33.3 \mathrm{a}$ & $23.8 \mathrm{~d}$ & $\ldots$ & $\ldots$ \\
\hline Benomyl & $\ldots$ & $\ldots$ & $41.4 \mathrm{bc}$ & $\ldots$ & $\ldots$ \\
\hline Canker removal ${ }^{\mathrm{z}}$ & $\ldots$ & $35.5 \mathrm{a}$ & $33.3 \mathrm{c}$ & $\ldots$ & $\ldots$ \\
\hline \multicolumn{6}{|c|}{ Disease severity (No. cankers per shoot) } \\
\hline Nonsprayed & $0.96 \mathrm{a}$ & $0.77 \mathrm{a}$ & $1.15 \mathrm{a}$ & $1.07 \mathrm{a}$ & $1.44 \mathrm{a}$ \\
\hline Chlorothalonil & $0.24 \mathrm{bc}$ & $0.20 \mathrm{c}$ & $0.17 \mathrm{e}$ & $0.54 \mathrm{~b}$ & $0.34 \mathrm{~b}$ \\
\hline Captan & $0.14 \mathrm{c}$ & $0.14 \mathrm{c}$ & $0.29 \mathrm{de}$ & $0.51 \mathrm{~b}$ & $0.25 \mathrm{~b}$ \\
\hline Myclobutanil & $0.43 \mathrm{~b}$ & $0.48 \mathrm{~b}$ & $0.77 \mathrm{~b}$ & $0.58 \mathrm{ab}$ & $0.32 \mathrm{~b}$ \\
\hline Copper & $\ldots$ & $0.55 \mathrm{ab}$ & $0.60 \mathrm{bc}$ & $\ldots$ & $0.47 \mathrm{~b}$ \\
\hline Azoxystrobin & $\ldots$ & $0.45 \mathrm{~b}$ & $0.32 \mathrm{~d}$ & $\ldots$ & $\ldots$ \\
\hline Benomyl & $\ldots$ & $\ldots$ & $0.72 \mathrm{~b}$ & $\ldots$ & $\ldots$ \\
\hline Canker removal ${ }^{z}$ & $\ldots$ & $0.53 \mathrm{ab}$ & $0.44 \mathrm{~cd}$ & $\ldots$ & $\ldots$ \\
\hline
\end{tabular}

${ }^{\mathrm{x}}$ For each type of disease assessment, means in the same column with the same letters do not differ significantly according to the Waller-Duncan $k$-ratio $t$ test at $P \leq 0.05$ and $k=100$. Each mean was calculated from five replicate trees with 50 shoots per tree.

${ }^{\mathrm{y}}$ Fungicides were applied during both fall and spring seasons; specific application dates for each year and season are given in Table 1.

${ }^{\mathrm{z}}$ Cankers were pruned in early to mid-September, which corresponds to the beginning of fall leaf abscission; prunings were allowed to remain on the orchard floor below trees. 
2). Myclobutanil, copper, and benomyl, and canker removal had similar effects on disease on Encore, ranging from 24.6 to $28.9 \%$ disease control. Very little difference in control capability was observed among treatments applied to the Jerseyglo block.

Consecutive usage. From 1997 to 1998 , the annual rates of change of disease incidence for the various treatments on each cultivar generally were not significantly different from zero (Table 5). In the Encore block, the incidence of cankers on the nonsprayed control trees declined by approximately $12 \%$, a change that was barely statistically significant. Although four and two of the fungicide treatments during the same period exhibited negative and positive rates, respectively, none were statistically significant. Disease levels on all fungicide-treated Jerseyglo trees declined from 1997 to 1998 as indicated by their negative rates. However, only the decrease of approximately $16 \%$ on trees treated with captan in fall + spring was significant.
Canker levels on the nonsprayed control trees in the Encore block increased significantly (17.7\%) from 1998 to 1999 (Table 5). A similar increase $(15.3 \%)$ in disease incidence followed fall-only applications of chlorothalonil. In contrast, the fall + spring treatment schedule for the same compound maintained disease incidence at the same level, as was evident from the nonsignificant $-1.18 \%$ rate of change. Among all treatments examined for application timing, the chlorothalonil fall + spring treatment was the most consistent across years in both cultivar blocks (Table 3). Although the captan spring treatment resulted in a highly significant decline in canker incidence from 1998 to 1999, the disease level was unusually high in 1998 relative to that of the nonsprayed control (Tables 3 and 5).

The canker removal data recorded in September 1997 allowed comparison across years for disease severity on infected shoots. For the 1997 fall pruning treatment, a mean of 1.88 cankers per in-

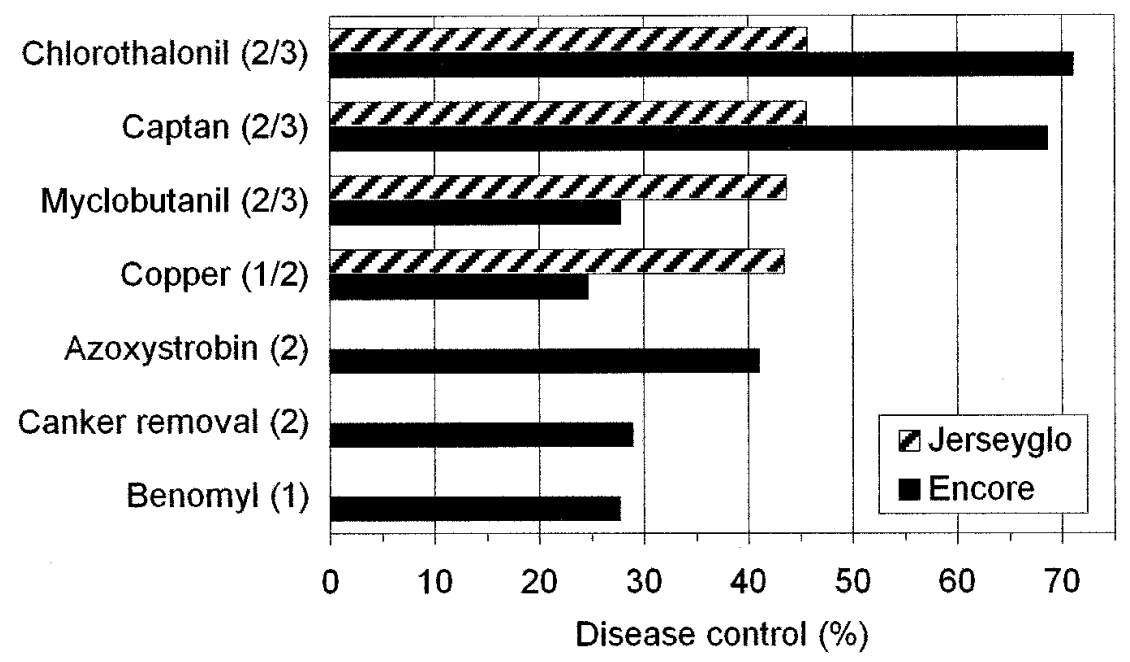

Fig. 2. Comparison of fungicides for control of peach constriction canker caused by Phomopsis amygdali. Numbers in parenthesis indicate the number of years of data used to calculate the percent disease control for cvs. Jerseyglo and Encore, respectively. All fungicides were applied during both fall and spring (Table 1). fected shoot was calculated with a range of 1.61 to 2.25 cankers per shoot. Means (ranges) for the 1998 and 1999 disease assessments were 1.46 (1.13 to 1.79$)$ and 1.32 (1.14 to 1.55$)$, respectively. Two-sided $t$ tests indicated that disease severity deceased significantly from 1997 to 1998 ( $P$ $=0.02$ ), but no change occurred between 1998 and $1999(P=0.31)$. This latter comparison agrees with the lack of a significant decrease in the rate of disease incidence observed between these 2 years (Table 5).

Incidence-severity relationship. The relationship between disease incidence (i) and severity (s) was similar for the Encore and Jerseyglo blocks, as indicated by the high degree of overlap of plotted data points (Fig. 3). When data from all years and both cultivars were combined, the power and quadratic models provided excellent and near-identical fits to the observed data. The exponential model clearly overestimated disease severity at $i<25 \%$, and exhibited a y-intercept of 0.155 cankers/shoot. These results do not agree with the biology of the relationship, which dictates that $s=0$ when $i=0$. In contrast, both the power and no-intercept quadratic functions pass through the origin.

When separate power models were fit to the Encore and Jerseyglo data sets, the resulting regression functions were $s=$ $0.00466 i^{1.33}\left(R^{2}=0.93\right)$ and $s=0.00227 i^{1.53}$ $\left(R^{2}=0.83\right)$, respectively. The parameter estimates for these two models appear quite different in value, particularly for the first coefficient. However, a comparison of full and reduced models indicated that the separate cultivar models were not statistically different overall $(F=0.028, P=$ 0.97), allowing the data to be pooled.

\section{DISCUSSION}

We conclude from the results of this study that the fall leaf abscission period is the most critical time for disease control. Application of chlorothalonil during the fall provided 45 to $63 \%$ disease control, while sprays applied in spring from budbreak to bloom provided only 10 to $28 \%$

Table 5. Annual rates of change of disease incidence of constriction canker for different fungicides and application timings in two commercial peach orchards

\begin{tabular}{|c|c|c|c|c|c|c|c|}
\hline & & \multicolumn{6}{|c|}{ Annual disease incidence rate (\% infected shoots per year) } \\
\hline & & \multicolumn{4}{|c|}{ Encore orchard } & \multirow{2}{*}{\multicolumn{2}{|c|}{$\begin{array}{c}\text { Jerseyglo orchard } \\
1997-1998\end{array}$}} \\
\hline \multicolumn{2}{|c|}{ Treatment } & \multicolumn{2}{|c|}{ 1997-1998 } & \multicolumn{2}{|c|}{ 1998-1999 } & & \\
\hline Fungicide & Timing & Rate & $P>t^{z}$ & Rate & $P>t^{2}$ & Rate & $P>t^{\mathrm{z}}$ \\
\hline Nonsprayed & $\ldots$ & -2.34 & 0.049 & 17.74 & $<0.001$ & 0.43 & 0.970 \\
\hline \multirow[t]{3}{*}{ Chlorothalonil } & Fall & 7.47 & 0.318 & 15.25 & 0.021 & -9.15 & 0.295 \\
\hline & Spring & -1.36 & 0.903 & -10.05 & 0.266 & -3.75 & 0.791 \\
\hline & Fall + spring & -2.64 & 0.559 & -1.18 & 0.759 & -4.73 & 0.671 \\
\hline \multirow[t]{2}{*}{ Captan } & Spring & 12.96 & 0.302 & -15.71 & 0.006 & -2.76 & 0.802 \\
\hline & Fall + spring & -1.52 & 0.680 & 8.82 & 0.117 & -16.33 & 0.036 \\
\hline Myclobutanil & Fall + spring & 4.17 & 0.475 & 13.59 & 0.041 & -9.89 & 0.089 \\
\hline Copper & Fall + spring & $\ldots$ & $\ldots$ & 5.78 & 0.450 & $\ldots$ & $\ldots$ \\
\hline Azoxystrobin & Fall + spring & $\ldots$ & $\ldots$ & -9.47 & 0.187 & $\ldots$ & $\ldots$ \\
\hline Canker removal & September & $\ldots$ & $\ldots$ & -2.17 & 0.651 & $\ldots$ & $\ldots$ \\
\hline
\end{tabular}

${ }^{\mathrm{z}}$ Significance probability associated with a $t$ test for the null hypothesis that the annual rate of change of disease incidence is equal to zero. 
disease reduction. Adding spring applications to the fall schedule provided only a small improvement of 0 to $8 \%$ disease control compared with fall-only treatments. This nonadditive effect was most likely due to prevention of canker formation by fall sprays, which thereby reduced available inoculum for spring infection. Consequently, spring fungicide applications provided fewer benefits following fall sprays than when spring applications were used in the absence of fall sprays. However, in the final year of the study, earlier spring sprays beginning at delayed dormant stage appeared to enhance the level of control. This latter observation indicated that infection might be occurring prior to bud-break.

Past studies comparing the relative importance of fall and spring applications have not been conducted. Nevertheless, work has been done to examine control during either season alone or in combination. In a New Jersey study examining control of spring infection, a single delayed dormant application of monocalcium arsenite plus Bordeaux mixture provided 96 and $94 \%$ reduction in spring cankers in 1951 and 1952, respectively (7). However, the period from delayed dormant through bloom was very short in these 2 years, while in 1953 this period lasted 6 weeks and the same fungicide mixture and timing only yielded $30 \%$ control. In the same experiment in 1953, application of three sprays at delayed dormant, pink, and fullbloom stages using ferbam, captan, and dichlone resulted in 25 to 35,48 to 62 , and $60 \%$ lower disease severity, respectively.
In our study, disease assessments were based on counts of all cankers from both fall and spring infections. Thus, results from our spring application treatments cannot be directly compared to those from this earlier study. Nevertheless, the improved control we obtained in 1999, when a delayed dormant spray was applied, agrees with the results from this earlier experiment. However, while the previous results indicated that fungicide applications after delayed dormant can significantly reduce the percentage of spring infections, our results showed that the number of these infections is small relative to the total number incited during both seasons.

In another New Jersey study conducted in 1952 to 1953 on cv. Jerseyland peach, Daines et al. (8) examined fall sprays of different fungicides applied at 14-day intervals from mid-August until completion of leaf abscission in November. To control spring infections, all trees received the same weekly spring sprays of ferbam from early pink through bloom. Canker counts performed the following spring during shuck-off agree with those obtained in our experiment using similarly scheduled fall and spring applications of chlorothalonil and captan on Encore.

A more recent disease control study was conducted in Alabama (17). Fall sprays, fall + spring sprays, and a single dormant spray were applied to cv. Sentinel peach trees during 1991 to 1992 . Disease intensity in the experiment was low, as only $29 \%$ canker incidence was observed on shoots of nonsprayed trees. The best treat-

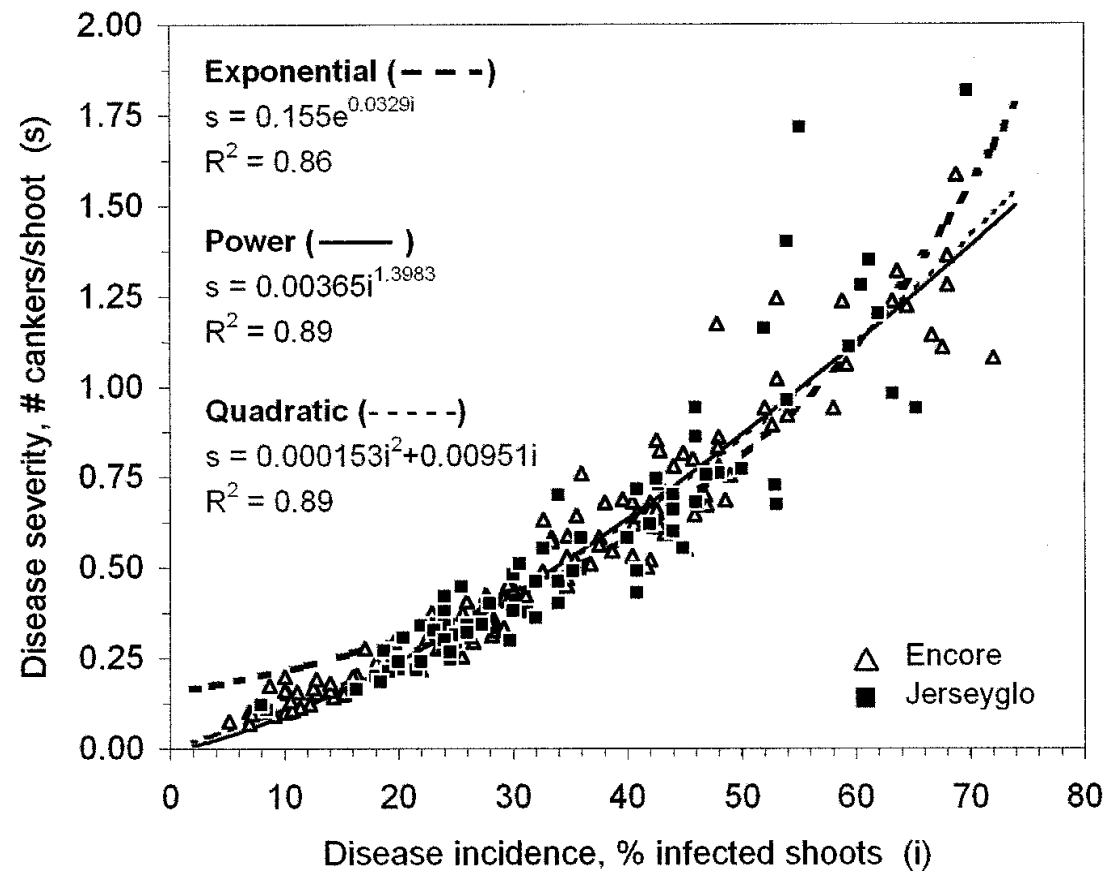

Fig. 3. Relationship between disease incidence and severity of constriction canker caused by Phomopsis amygdali on two peach cultivars. Plotted data points represent values calculated from individual trees with 50 shoots per tree; observations on all treatments from 1997 to 1999 are included. Functions were fit to all data for both cultivars (reduced model) using nonlinear regression analysis; $R^{2}=1-[\mathrm{SS}($ error $) / \mathrm{SS}($ corrected total) $]$. ment, chlorothalonil applied in the fall and spring, resulted in $14 \%$ disease incidence, which translated into $48 \%$ control, however, none of the treatments were significantly different from the nonsprayed treatment. Unlike our study and those conducted previously in New Jersey, only three fall applications at 3-week intervals and three late spring applications at pink, full bloom, and petal fall were applied in the Alabama experiment. Given our findings, we believe that inadequate control in that study may have been due to poor spray coverage throughout the critical fall leafdrop period and lack of an early dormant spray. Our best treatment in any one year was the 1998 to 1999 fall + spring chlorothalonil schedule on Encore, which provided $78 \%$ control under relatively heavy disease pressure.

The broad-spectrum protectant fungicides chlorothalonil and captan provided significantly better control than the representative triazole (myclobutanil), strobiliurin (azoxystrobin), benzimidazole (benomyl), or copper compounds. For most of these fungicides, the rates used were at the high end of the recommended rate range so that an adequate, effective residue would likely be present. Also, a short to moderate spray interval combined with a spray volume set at one-half of the full-dilute level were used to insure sufficient coverage during the critical periods. A past study focusing on fall infection (8) showed similar control capability with captan, thiram, and ferbam as obtained in our study with captan and chlorothalonil. In contrast, a more recent study examining spring infection showed a different benzimidazole fungicide, carbendazim, to be very effective while captan was ineffective; however, only three applications of captan at twothirds our rate were applied (19).

The efficacy of various fungicides was recently compared on detached cv. Jerseyqueen peach shoots that were artificially inoculated with Phomopsis conidia and incubated in moist chambers for 21 days (17). The best control with $89 \%$ healthy shoots, was achieved with the triazole bitertanol, while another triazole, propiconazole, provided only $44 \%$ control; sulfur, lime sulfur, and iprodione all failed to provide any control. The chlorothalonil treatment in that study provided good control, protecting $78 \%$ of shoots. Two benzimidazoles examined, benomyl and thiophanate methyl, had $0 \%$ control, which agrees with the low $28 \%$ control achieved with benomyl in our study. However, the captan treatment only protected $11 \%$ of the detached shoots, while this fungicide protected $68 \%$ of shoots in our field studies. An earlier New Jersey study also showed good control with captan (8). This disparity in findings may be due to the lower concentration of captan tested, which was only half of that examined in our study and twothirds of that in the earlier study. 
Pruning cankers from tree canopies was partially successful as a disease control measure. Although a disease reduction was not observed in 1998, the number of multiple infections from 1997 to 1998 and the canker incidence and severity in 1999 were significantly reduced. In this final year of the study, canker removal afforded a $42 \%$ increase in disease control. These results agree with those recently reported from Georgia, where an average 37 and $43 \%$ control was achieved over the 1994 to 1996 period for canker-pruned trees with shoot debris remaining under the canopy (22).

In contrast to the Georgia experiment (22), cankers were not regularly pruned from buffer trees in our study. Thus, movement of pathogen conidia from adjacent trees by wind-driven rain appears likely, while movement of inoculum upward from the canopy floor seems less likely. And unlike cultural control via canker removal, fungicides would protect shoots regardless of inoculum source. Given these results, we believe that canker removal might provide effective though incomplete control when practiced on a large whole-block scale as would be done commercially. However, in some heavily infected commercial orchards, significant inoculum reduction from canker removal may not be possible, as the labor cost would be prohibitive.

Previous research indicated that at least 3 years of fall, dormant, and spring fungicide applications plus regular canker removal were needed to rehabilitate severely infected peach orchards (12). Although consecutive years of fungicide application resulted in continued reduction of disease incidence for many of our treatments, the vast majority of these rates of decline were not statistically significant. Indeed, significant reductions in disease levels were observed after the first year of spray applications. However, incidence levels obtained were still higher than would be expected for an effective program.

Ideally, an effective fungicide program would have provided at least $90 \%$ disease control. Of course, in this experiment, one possible explanation for the less than ideal control may be that all fungicides examined had only low to moderate toxicity against $P$. amygdali. However, another distinct possibility relates directly to the experimental design. Although frequent sprays of fungicides at high rates were used during the critical fall and spring periods, the single-tree plots were surrounded by severely infected non-sprayed trees. Consequently, high inoculum levels may have resulted in greater disease intensity on treatment trees than would have been observed in larger plots. This phenomenon may also explain why we were not able to significantly lower infection levels or rehabilitate individual trees over time. Certainly, this situation would not be present in commercial blocks.
Inoculum from pycnidia has been shown to be available during all seasons (16). Thus, another potential cause for less than ideal control may have been infection occurring during the summer or winter. Some summer infection through fruit scars after June drop, thinning, and harvest may have occurred during our study, as $6 \%$ of nodes examined after either of these events had become infected on highly susceptible cv. Raritan Rose peach (4). However, significant infection at these times was not considered likely. Captan applied to all treatments during the early summer cover sprays should have helped to reduce the incidence of infections through fruit scars. Furthermore, warmer temperatures, as experienced during summer, have been shown to decrease the susceptibility of leaf scars (4). This phenomenon may be due to a higher rate of suberization and periderm formation at warmer temperatures, but additional research is needed to confirm this relationship. Infection also may have occurred directly through dormant buds, which has been recently demonstrated (23). In each winter of our study, moderate temperature periods were recorded at the Rutgers Agricultural Research and Development Center, located approximately $13 \mathrm{~km}$ from the orchard sites. Winter rains frequently accompanied these warm periods, and because our treatment trees were not protected during the winter, infections may have been initiated.

Estimation of disease severity, measured as number of cankers per shoot, is important for determining the impact of constriction canker on yield loss (14). Since only those fruit distal to cankers abscise and drop off, multiple shoot infections increase the probability that a greater proportion of fruit would be lost to production. However, direct estimation of severity by counting cankers is time consuming, making it difficult to survey large numbers of commercial blocks. In contrast, incidence assessments are much more quickly performed, only requiring observation of blighted shoots. Thus, the derived models should allow for prediction of severity from the more easily obtainable incidence observations. Furthermore, since the incidence-severity relationship was shown to be similar for both cultivars, the same models may have universal applicability. However, research on additional cultivars is needed to confirm that the relationship remains constant.

Two main objectives of this study were to determine the relative importance of fall versus spring fungicide applications and to compare the efficacy of various fungicide chemistries. To insure that spray coverage through each season was not a limiting factor in control, high fungicide rates and frequent applications were employed. Although the economics of yield loss in moderate to severely infected orchards supports eight or more fungicide applications per season (14), we do not believe that this many applications will ultimately be necessary. Epidemiological studies are currently in progress that should allow improved application timing within each season, thereby maintaining acceptable control with a minimum number of sprays. In addition, canker removal and fungicide applications should be investigated more fully as an integrated form of disease management. Finally, experimentation is needed to examine the importance of infection during the dormant period.

\section{ACKNOWLEDGMENTS}

We thank D. A. Rosenberger for reviewing the manuscript and DeCou Hilltop Orchards for providing peach blocks for experimentation.

\section{LITERATURE CITED}

1. Adaskaveg, J. E., and Förster, H. 1999. First report of fruit rot and associated branch dieback of almond in California caused by a Phomopsis species tentatively identified as $P$. amygdali. Plant Dis. 83:1073.

2. Belding, R. D., Hamilton, G. C., Heckman, J. R., Katz, L. S., Lalancette, N., Majek, B. A., and Shearer, P. W. 1997. New Jersey commercial tree fruit production guide. Rutgers University Cooperative Extension Bulletin E002J.

3. Cohoon, D. F., and Daines, R. H. 1954. Some facts about peach canker. (Abstr.) Phytopathology 44:109.

4. Cohoon, D. F., and Daines, R. H. 1956. Peach canker (Fusicoccum amygdali): times and sites of infections. Plant Dis. Rep. 40:304308.

5. Daines, R. H. 1974. Peach canker (Fusicoccum amygdali Delacroix) present in orchards in Hammonton area. Hortic. News, The New Jersey State Hortic. Soc. 55(4):12-13.

6. Daines, R. H., and Cohoon, D. F. 1953. Peach canker and suggestions for its control. Hortic News, The New Jersey State Hortic. Soc. 34:2621-2637.

7. Daines, R. H., and Cohoon, D. F. 1954. Control of peach canker. (Abstr.) Phytopathology 44:109.

8. Daines, R. H., Cohoon, D. F., Leone, I., and Brennan, E. 1958. Control of Fusicoccum canker of peach by nutrition, defoliation, and protective fungicides. Phytopathology 48:400-407.

9. Farr, D. F., Castlebury, L. A., and PardoSchultheiss, R. A. 1999. Phomopsis amygdal causes peach shoot blight of cultivated peach trees in the southeastern United States. Mycologia 91(6): 1008-1015.

10. Guba, E. F. 1953 . Peach canker caused by the fungus Fusicoccum persicae E. \& E. (Abstr.) Phytopathology 43:109.

11. Guba, E. F. 1955. Some historical aspects of peach canker caused by the fungus Fusicoccum amygdali Delacr. Plant Dis. Rep. 39:771772 .

12. Guba, E. F. 1958. Pertinent aspects of the infection cycle and control of the peach canker pathogen, Fusicoccum amygdali. Plant Dis. Rep. 42:481-492.

13. Haenseler, C. M., and Daines, R. H. 1941 Peach canker caused by Fusicoccum amygdali. (Abstr.) Phytopathology 31:10.

14. Lalancette, N., and Polk, D. F. 2000. Estimating yield and economic loss from constriction canker of peach. Plant Dis. 84:941-946.

15. Lalancette, N., and Robison, D. M. 2000 Comparison of management strategies for constriction canker of peach. (Abstr.) Phytopathology 90:S44.

16. Lalancette, N., and Robison, D. M. 2001. Seasonal availability of inoculum for con- 
striction canker of peach in New Jersey. Phytopathology 91:1109-1115.

17. Latham, A. J. 1994. Phomopsis dieback of peach shoots. Pages 116-120 in: Stone Fruit Tree Decline, Sixth Workshop Proceedings. A. P. Nyczepir, P. F. Bertrand, and T. G. Beckman, eds. U.S. Dept. of Agriculture, Agricultural Research Service. ARS-122.

18. Latham, A. J., Morgan-Jones, G., and Campbell, H. L. 1992. Phomopsis dieback of peach shoots in Alabama. Plant Dis. 76:426.

19. Montero, J. C., Espósito, S. M., González de las Heras, B., and Marsili, R. C. A. 1987. Evaluación de fungicidas en el control de la viruela de la pua (Fusicoccum amygdali) en duraznero. Bol. Téc. Est. Exp. Mercedes 7(4):71-76.

20. Roberts, J. W. 1940. The constriction disease of peach. Phytopathology 30:963-968.

21. Tuset, J. J., and Portilla, M. T. 1989. Taxonomic status of Fusicoccum amygdali and Phomopsis amygdalina. Can. J. Bot. 67:12751280.

22. Uddin, W., and Stevenson, K. L. 1998. Seasonal development of Phomopsis shoot blight of peach and effects of selective pruning and shoot debris management on disease incidence. Plant Dis. 82:565-568.
23. Uddin, W., Stevenson, K. L., and PardoSchultheiss, R. A. 1997. Pathogenicity of a species of Phomopsis causing a shoot bligh on peach in Georgia and evaluation of possible infection courts. Plant Dis. 81:983-989.

24. Weaver, L. O. 1951. The constriction disease of peach in Maryland. Plant Dis. Rep. $35: 144$.

25. Zehr, E. I. 1995. Constriction canker. Pages 31-32 in: Compendium of Stone Fruit Diseases. J. M. Ogawa, E. I. Zehr, G. W. Bird, D. F. Ritchie, K. Uriu, and J. K. Uyemoto, eds. The American Phytopathological Society, St. Paul, MN. 